\title{
REFERENCES.
}

Geological Survey Map, Sheet 7 (Drift Edition, I871). Price 18s. 6d.

Geological Súrvey Index Map, Sheet I2. Price 2s. 6d.

Ordnance Survey Map.(New Series), Sheet $23^{8}$.

1854. Prestwich, J.- "On the Strata between the London Clay and the Chalk, etc." Quart. Fourn. Geol. Soc., vol. x, p. 90.

I878. Hopkinson, J.- "Excursion to Tyler's Hill, Chesham." Record of Excursions, p. 228.

1889. WhItAKER, W.- "Geology of London." Mem. Geol. Survey, vol. i, P. I94.

I890. PRESTWICH, J.- "Relation of the Westleton Beds, etc." Quart. Fourn. Geol. Soc., vol: xlvi, p. I 39 .

I896. SALTER, A. E.- " "Pebbly Gravel' from Goring Gap to the Norfolk Coast." Proc. Geol. Assoc., vol. xiv, p. $3^{89}$.

\section{EXCURSION TO AYLESBURY, HARTWELL, AND STONE.}

\author{
SATURday, APRil IOTh, 1897. \\ Directors : A. M. Davies, B.Sc., F.G.S., and \\ Percy Emary, F.G.S. \\ Excursion Secretary : H. A. Allen, F.G.S. \\ (Redort by THE DIRECTORS.)
}

ABout twenty-three members assembled at Aylesbury (Metropolitan Railway) shortly after 3 p.m., and were led without delay along a field-path to Locke's clay-pit, on the Thame road, about a mile and a quarter out of Aylesbury. Here Mr. Davies briefly explained the objects of the excursion. It was nearly ten years, he said, since the Association had visited this district, which was probably new ground to many present. To the east and south the Chalk escarpment of the Chilterns was conspicuous. The vale at the foot of it was marked on the geological map as occupied mainly by Gault and Kimeridge Clays, between the outcrops of which two clays came an apparently irregular and discontinuous series of patches mapped as Portland Sand, Portland Stone, Purbeck, and Lower Greensand. The ground on which they were then standing was mapped as Kimeridge Clay, but the fossils which had made this pit famous indicated a higher horizon than the highest proper Kimeridgian, and though for mapping purposes it was impossible to separate it from Kimeridge Clay, it was better to speak of it as Hartwell Clay, and to include it, as Mr. JuLv, I897.] 
H. B. Woodward did, in the Lower Portlandian. (Professor Pavlow, in his recent paper,* went further, and called it Middle Portlandian.) It followed that the beds mapped as Portland Sand in this district did not represent the horizon known by that name in the southern counties, but, along with the Portland Stone above, were Upper Portlandian.

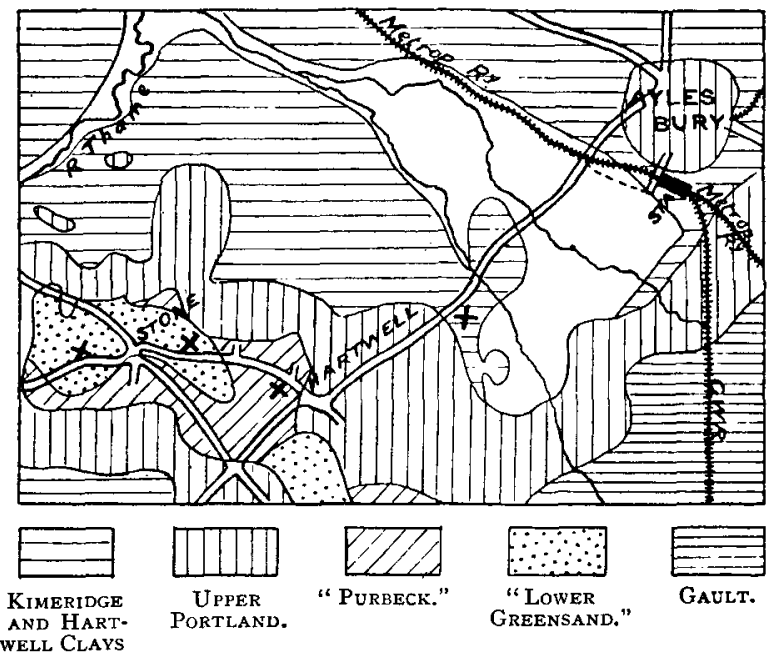

Fig. I.-Geological Sketch Map of the District West of Ayi.esbuky.

(After the Survey Map.)

Scale: $\mathrm{I}$ inch $=\mathrm{I}$ mile.

Areas left blank, Alluvium and Gravel.

Exposures visited- $\times$. These are, in order from right to leftLocke's clay-pit; the Bugle pit; the "old sand-pit," Stone; and the Windmill pit.

The President (Mr. E. T. Newton) called attention to the fact that a collection of shells from these beds had been made some years ago by the late Dr. E. Lee, which included many forms of a peculiar type and beautifully perfect. These shells are still preserved in Dr. Lee's museum at Hartwell House.

The spoil-heaps were not in as good a condition as might be wished, but a number of the characteristic fossils were soon obtained, including:

* Quart. Journ. Geol. Soc., vol. lii, p. $54^{2}$ (August, 1896). 
Arca longipunctata, Blake.

Astarte hartwellensis, Sow.

" mysis, d'Orb.

Modiola pectinata, Phil. non Sow.

Pecten lens, Sow. var. morini, de Lor.

Perna mytiloides, Lam.

Pholadomyia proteii, Ag.

Thracia depressa, Sow.

Trigonia voltzii ?, Ag.

Ammonites (Perisphinctes) biplex, Sow.

Belemnites explanatus, Phil.

The Thame road was next followed for nearly a mile, when another pit was reached. This lies a little beyond the "Bugle Horn" Inn, and has therefore become known as the "Bugle Pit." By some curious slip it has twice been referred to in geological literature as the Beagle Pit.*

The succession of the beds here was pointed out by Mr. Emary. The beds seen were those shown on the accompanying section (Fig. 2), from the top down to and including the gritty limestone, No. 5. The sand bed, No. 4 , and the rubbly limestone, No. 3, were exposed in a pit sunk at this spot when the Association visited Hartwell in $1887 .+$ The limestone, No. 3 , is here almost unfossiliferous, but is believed to be the equivalent of a very fossiliferous bed, which was-exposed at the town of Aylesbury when the drainage works were being carried out. Mr. Emary called attention to the fact that Ostracods have been recorded by Prof. Rupert Jones+ from this locality, not only in the Purbeck beds but also in the upper bed of the Portland No. 9. It is interesting to learn that some of the forms described from this bed are marine, whilst others are freshwater. There is a similar mingling of marine and freshwater forms in the lower part of the Purbeck beds, whilst in the upper part freshwater forms only are met with. This appears to indicate a gradual transition from the marine conditions of the Portland to the freshwater conditions of the Purbeck episode, and that the two series are conformable to each other in this district. There is, however, a considerable amount of erosion in the Purbeck beds themselves, the marly beds with limestone bands being scooped out into hollows, occupied by a greyish clay.

The fossils recorded from the Purbeck beds of this district include several species of Cyrena, Paludina (Vivipara), etc., together with fish remains, plants, and insects. Unfortunately no record appears to have been made of the exact horizon from which they were obtained, i.e., whether above or below the line

* Quart. Joum, Geol. Soc., vol. xlix, p. 566 ; Proc. Geol. Assoc., vol. xiv, p. 31.

+ Proc. Geol. Assoc., vol, x, p r6g.

$¥$ Quart.Journ. Geal. Soc., vol xl p. 328 . 


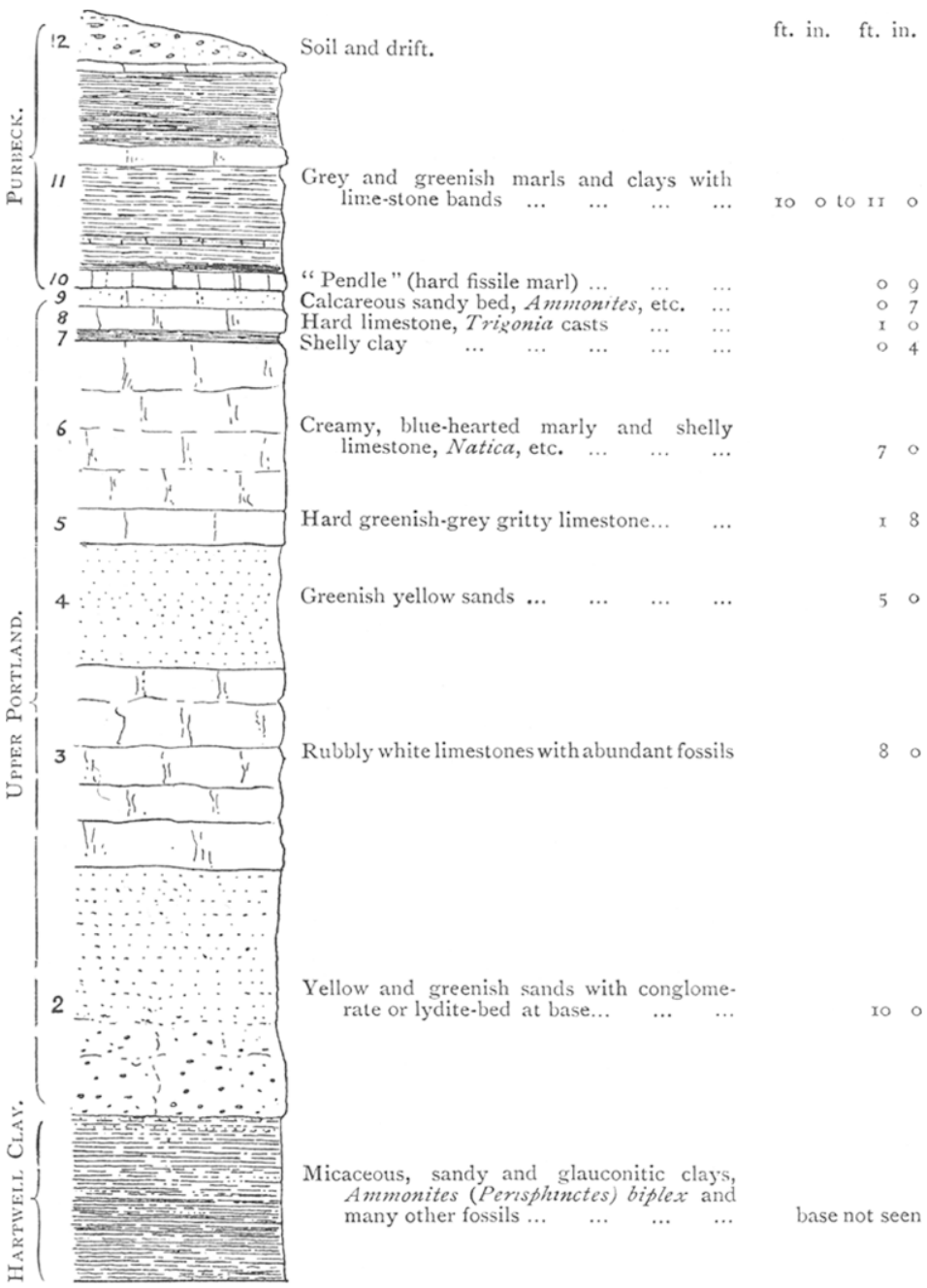

Fig. 2.-General Sectioniat, Ailesbury.-H. B. Wordzara. 
of erosion. More detailed work is therefore needed before the age of the upper clayey beds, above alluded to, can be regarded as settled. With regard to the marly beds, reference was made to the view of Prof. Blake, namely, that they are the freshwater equivalent of the marine Portland Stone of the coast. Prof. Blake correlates the creamy limestones of Hartwell with the Trigonia beds of Swindon, and with the lower part of the flinty series of the Isle of Portland. This would leave the remainder of the flinty series and the whole of the building stone series of the Isle of Portland unrepresented here unless they are represented in part of the marly beds mapped as "Purbeck." A number of casts of Trigonia were obtained by members of the party, and Cardium dissimile was found to be very abundant. Several fish scales and vertebræ were found in the "Pendle," and one of the large Ammonites so common in the district (Perisphinctes boloniensis) was seen in sitû in the creamy limestone.

Those members who could be induced to tear themselves away from this famous fossil locality were now conducted along the road for another half-mile or so to what may be referred to as the "Old Sandpit," Stone, for want of a more accurate name. Accuracy, however, is very needful in dealing with a series of beds so changeable as these sands, and it is most regrettable that some of the sections described by Fitton and Morris are very difficult to localise now. It may, therefore, be advisable to state that this is the pit distinctly marked on the six-inch map, almost opposite "Stone Farm," and extending northwards from the road half-way to a little coppice.

The section here shows 9 feet of sand, pure white for the most part, but slightly carbonaceous in places. Above this comes 2 feet of clay (including beds of clayey sand); and at the eastern end of the pit there comes on above this a very distinct bed of pebbly carstone, consisting of pebbles of quartz and "lydite," firmly cemented by iron oxide.

Mr. Davies here explained that these sandy beds were mapped as "Lower Greensand," but they might be of any age between the "Purbeck" and the Gault. Ten miles to the north-east began the regular outcrop of the marine sands, whose fossils proved them to be of undoubted Aptian age (i.e., of the age of the Hythe, Sandgate, and part of the Folkestone beds, and the Tealby limestone). The same fossils had been found fifteen miles to the west-south-west, at Toot Baldon. But between these two points came a series of scattered outliers of sands, in some of which (as at Shotover and Brill) freshwater fossils, possibly of Wealden age, had been found.

Mr. Teall long ago called attention to the fact that these scattered patches rested upon Portland or Purbeck, while the marine sands rested on Kimeridge or on Oxford Clay, and he suggested that there were two distinct series here-an older fresh- 
water and a newer marine one.* To complicate matters, Professor Morris had described the sands they were now upon as containing marine fossils, and derived blocks with freshwater fossils. It was evident, therefore, that we still had something to learn before we could finally decide the age of these sands.

A move was next made to the new pit now worked on the north side of the Thame road, close to the Windmill and very near the site of an old pit described by Fitton. Here were seen nine feet of white sand, beautifully false-bedded, with bands of pebbles, carbonaceous bands, and some concretions. Above these, with an apparent unconformity 'due, no doubt, to contemporaneous truncation of the false-bedded sands), came some 5 or 6 feet of clay, with ironstone bands near the base. This clay has considerable resemblance to one mapped as Gault near Dinton, and at first the Director had thought it might be Gault. But it contains no fossils of any kind, and more careful correlation of the different exposures had led him to the conclusion that it was strictly a part of the "Lower Greensand," whatever that might be. He was glad to find that Mr. Cameron, who had just started Survey work in the district, had come to just the same conclusion.

Time did not permit of a visit to the pits along the Eythrope road, where red sand replaces the white. The road was retraced to Aylesbury, and tea at the Vale of Aylesbury Hotel terminated a very successful excursion.

\section{REFERENCES.}

Geological Survey Map (I-inch scale), Sheet 46 (S. W.). Prlce 3i-.

Geological Survey Index Map, Sheet 12. Price 2/6.

Ordnance Survey Map (New Series), (I-inch scale), Sheet 237. Price I/-.

1836. W. H. FitTon.—- "Strata below the Chalk." Trans. Geol. Soc., ser. 2, vol. iv, p. 163.

I867. John MORRIS.- "On the Ferruginous Sands of Buckinghamshire." Geol. Mag., dec. r, vol. iv, p. 456 .

1873. - "Excursion to Aylesbury." Proc. Geol. Assoc., vol. iii, p. 210.

I880. J. F. BLAKE - "Portland Rocks of England." Quart. Gourn. Geor. Soc, vol. xxxvi, p. 189 .

I880. W. H. HudLEston.- "Excursion to Aylesbury." Record of Excursions, p. 230.

I 887. -- "Excursion to Aylesbury." Proc. Geol. Assoc.,

1895. H. B. WOODWARD.-." Jurassic Rocks of Britain," vol. v, pp. 220-229, 278-280. Mem. Geol. Survey.

- Potton and Wicken Phosphatic Deposits, p. 32. 